\title{
Ichthyofauna from the Parque Nacional da Serra dos Órgãos and its surrounding areas, Rio de Janeiro state, Brazil
}

\author{
Geysa da S. Camilo ${ }^{1}$, Bianca de F. Terra ${ }^{2 *}$ and F. Gerson Araújo ${ }^{1}$ \\ 1 Universidade Federal Rural do Rio de Janeiro, Departamento de Biologia Animal, Laboratório de Ecologia de Peixes, BR 465, Km 7, \\ 23890-00, Seropédica, RJ, Brazil \\ 2 Universidade Federal do Ceará, Centro de Ciências, Departamento de Biologia, Secretaria do Programa de Pós-Graduação em Ecologia e \\ Recursos Naturais, CEP 60.455-760, Fortaleza, CE, Brazil \\ * Corresponding author. E-mail: biancafterra@gmail.com
}

\begin{abstract}
This study provides a list of freshwater fishes of the Parque Nacional da Serra dos Órgãos (PARNASO; Rio de Janeiro state, Brazil) and its surrounding areas. Fish samplings were performed by electrofishing during the dry season (2010 -2011) in three different areas: 1, inside of the PARNASO (2 sites); 2, in the buffer zone (4 sites); and 3, in adjacent areas (8 sites). A total of 47 fish species in 13 families and six orders were recorded. Fish composition within the limits of the PARNASO differed from that recorded in the adjacent area, with the latter having comparatively higher species richness. The buffer area had intermediate ichthyofauna composition between the two other areas. This study enhanced knowledge on the composition and structure of the fish assemblages in PARNASO, by recording the occurrence of six new species within the park that were not included in the Management Plan of this Conservation Unit.
\end{abstract}

Key words: fish, Serra do Mar, Atlantic Rain Forest streams, conservation unit

\section{INTRODUCTION}

The Atlantic Rain Forest, located mostly on the eastern Brazilian coast, presents high species richness but it is under heavy anthropogenic pressure that has devastated large forested areas (Ribeiro et al. 2009). This tropical forest was one of the largest biomes in the Americas, covering ca. 150 million ha (Ribeiro et al. 2009). The early exploitation of the forest dates from the beginning of the colonization of Brazil, 500 years ago. Nowadays, only $12.9 \%$ of its original cover remains forested (Tabarelli et al. 2010). The majority of remaining forest cover are small fragments (<100 ha) while the largest forested areas are located in cliffs and stepped areas that difficult access of humans (Ranta et al. 1998; Silva et al. 2007; Ribeiro et al. 2009). Because heavy vegetation losses and high endemism degree, the Atlantic Rain Forest is considered one the largest hotspots in the world (Myers et al. 2000; Miranda 2012). The Atlantic Rain Forest has a rich ichthyofauna, estimated about 270 species, belonging to 89 genera and 21 families (Abilhoa et al. 2011; Miranda 2012). However, there are several doubts on species descriptions and on the ecological processes such as heavy water turmoil and vegetation influences on fish assemblages (Guimarães et al. 2010). Despite the high biodiversity in the Atlantic Rain Forest, anthropogenic activities have jeopardized this system and there are few studies on streams fish composition and structure (Myers et al. 2000; Miranda 2012).

Conservation Units have been proposed to mitigate human impacts on biodiversity. The Parque Nacional da Serra dos Órgãos (hereafter PARNASO) (Figure 1), one of the oldest Brazilian conservation units, was created in 1939, and nowadays occupies an area of 20,024 ha, covering parts of four municipalities of the Rio de Janeiro state: Petrópolis, Teresópolis, Magé and Guapimirim (ICMBio 2014). This conservation unit is one of the most important areas of environmental preservation of the Atlantic Rain Forest biome, located in a strategic area of the Serra do Mar. However, knowledge on the ichthyofauna from PARNASO is scarce because of the difficulty to access streams and rivers in the area, where headwaters are located in cliffs and steep park areas, with numerous waterfalls.

This study provides a list of freshwater fish species occurring in the PARNASO and surrounding areas. The surrounding areas were divided into two zones: 1, buffer zone, which is subject to specific rules and restrictions to minimize anthropogenic impacts on the surrounding park area; and 2, adjacent area, which is the surrounding the buffer zone where the conservation unit rules do not reach. We also evaluated the role of the environment protection on the fish assemblage, as well as the 


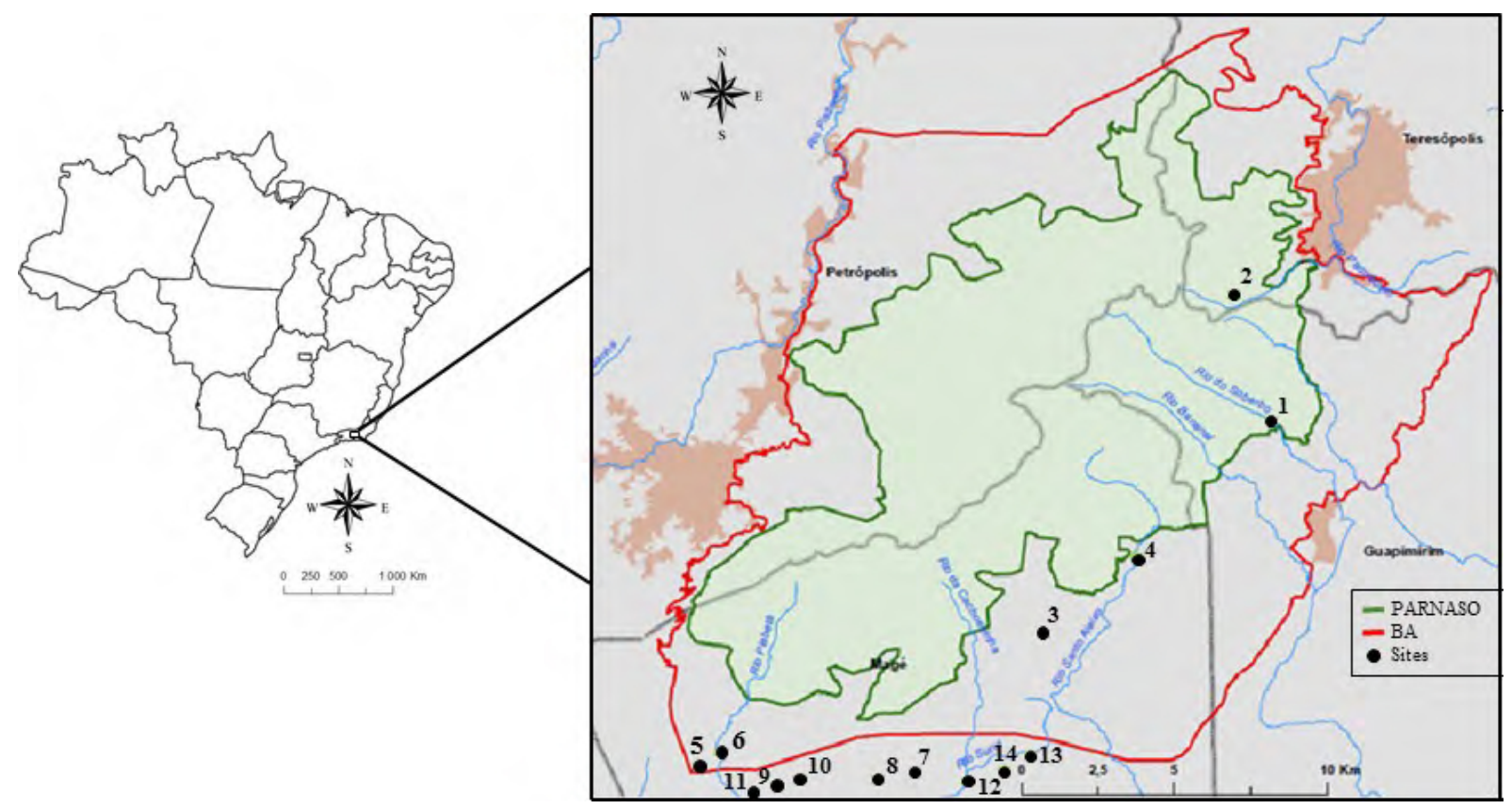

Figure 1. Map of the study area, indicating the 14 Atlantic Forest stream sites, in the Parque Nacional da Serra dos Órgãos (PARNASO) and its surrounding areas, southeastern Brazil. BA= Buffer area. Map given by Parque Nacional da Serra dos Órgãos (adapted). The altitude of the sites is given in Table 1.

consequences of impacts from non-protected areas on fish assemblage diversity. Although only the most accessible sites were searched, we also describe fish structure assemblage. We believe this study can contribute to an update of species composition in reference to the management plan estimates and reinforce the importance of conservation unit on fish diversity maintenance.

\section{MATERIALS AND METHODS \\ Study Area}

This study was carried out in the Parque Nacional da Serra dos Órgãos (PARNASO) and its surrounding areas, in Rio de Janeiro state, southeastern Brazil (latitudes $22^{\circ} 25^{\prime} 00^{\prime \prime}-22^{\circ} 38^{\prime} 44^{\prime \prime} \mathrm{S}$; longitudes $042^{\circ} 45^{\prime} 36^{\prime \prime}$ - $043^{\circ} 26^{\prime} 57^{\prime \prime} \mathrm{W}$ ) (Figure 1). This area is bounded by the Serra do Mar coastal range, with altitudes between 300 and 2,263 $\mathrm{m}$ above sea level (Bragagnolo and Pintoda-Rocha 2003). The climate is tropical super humid, with the relative humidity remained between $80 \%$ and 90\%, reaching $99 \%$ at higher altitudes (Drummond 1997; Bragagnolo and Pinto-da-Rocha 2003). Average annual temperature is $18^{\circ} \mathrm{C}$ and rainfall ca. $2,300 \mathrm{~mm}$ (Guimarães et al. 2009). The wet season peaks during the summer (December to March) and dry season in the winter (June to August).

\section{Sampling design}

The streams sampling sites included in this study were distributed inside of the PARNASO area, in its buffer area, and in the adjacent area. The buffer area is defined according to the Brazilian law ( $n^{\circ}$ 9.985/2000) as the area in which human activities are subject to specific rules and restrictions to minimize anthropogenic impacts on the surrounding park area and to reduce damage on the conservation unit. The adjacent area is located near to the park but is not subject to conservation rules.

Fish and habitat surveys were conducted at 14 sites, which drain to Guanabara Bay in the Atlantic Rain Forest biome (Permit $\left.n^{\circ} 17632-2 / I C M B i o\right)$, distributed within the PARNASO limits (2 sites), in the buffer area (4), and in the adjacent area (8) (Figures 1 and 2). The sites were chosen on the basis of accessibility, and they are first to third streams order, with mean stream width ranging from 0.5 to $15 \mathrm{~m}$ (Table 1). Fish samplings were carried out during the dry season (May to October) in 2010 (12 sites) and 2011 (2 sites) to standardize the seasonal context. As descripted in Terra et al. (2013), a site was extended upstream for 40 times the mean wetted channel width, or a minimum of $100 \mathrm{~m}$ and a maximum of $500 \mathrm{~m}$.

Each site was surveyed by electrofishing, with alternating current generator $(3000 \mathrm{~W}, 110 / 220 \mathrm{~V})$ provided by two hoop-shaped (440 $\mathrm{mm} \times 300 \mathrm{~mm}$ ) anodes supporting a net ( $3 \mathrm{~mm}$ mesh). Two people, each with an anode, fished from one edge to the other removing all fishes detected in the electric field. All collected fish were fixed in 10\% formalin and, after 48 hours, preserved in $70 \%$ ethanol. All individuals were identified to species, counted and weighed (g). Vouchers were deposited in the fish collection of the Laboratory of Fish Ecology, Universidade Federal Rural do Rio de Janeiro and in the Special Teleost an Fish Collection of the Universidade Federal do Rio de Janeiro (Appendix 1).

\section{Statistical test}

We calculated abundance (N), biomass (B) and frequency of occurrence (FO\%) to each species for a 
fish assemblage description (Table 2). The frequency of occurrence was calculated from the number of samples in which each species was observed in relation to the total number of sampling sites. The abundance and biomass were calculated based on the total of individuals and weights for each species, respectively.

With the objective of identify differences in fish assemblages composition among areas (PARNASO, buffer zone, and adjacent area), we performed a Non-Metric Multidimensional Scaling (MDS). The resemblance matrix was based on Bray Curtis similarity and this analysis was performed in PRIMER 6 with PERMANOVA+ software (Clarke and Gorley 2006).

\section{RESULTS}

We collected a total of 4,617 individuals belonging to 47 species, 13 families and six orders (Table 2). Siluriformes represented $42.6 \%$ (20 species) of the total number of species, followed by Characiformes with 32\% (15 species). Cyprinodontiformes were represented by six species, Perciformes by three, Gymnotiformes by two and Synbranchiformes by only one species.
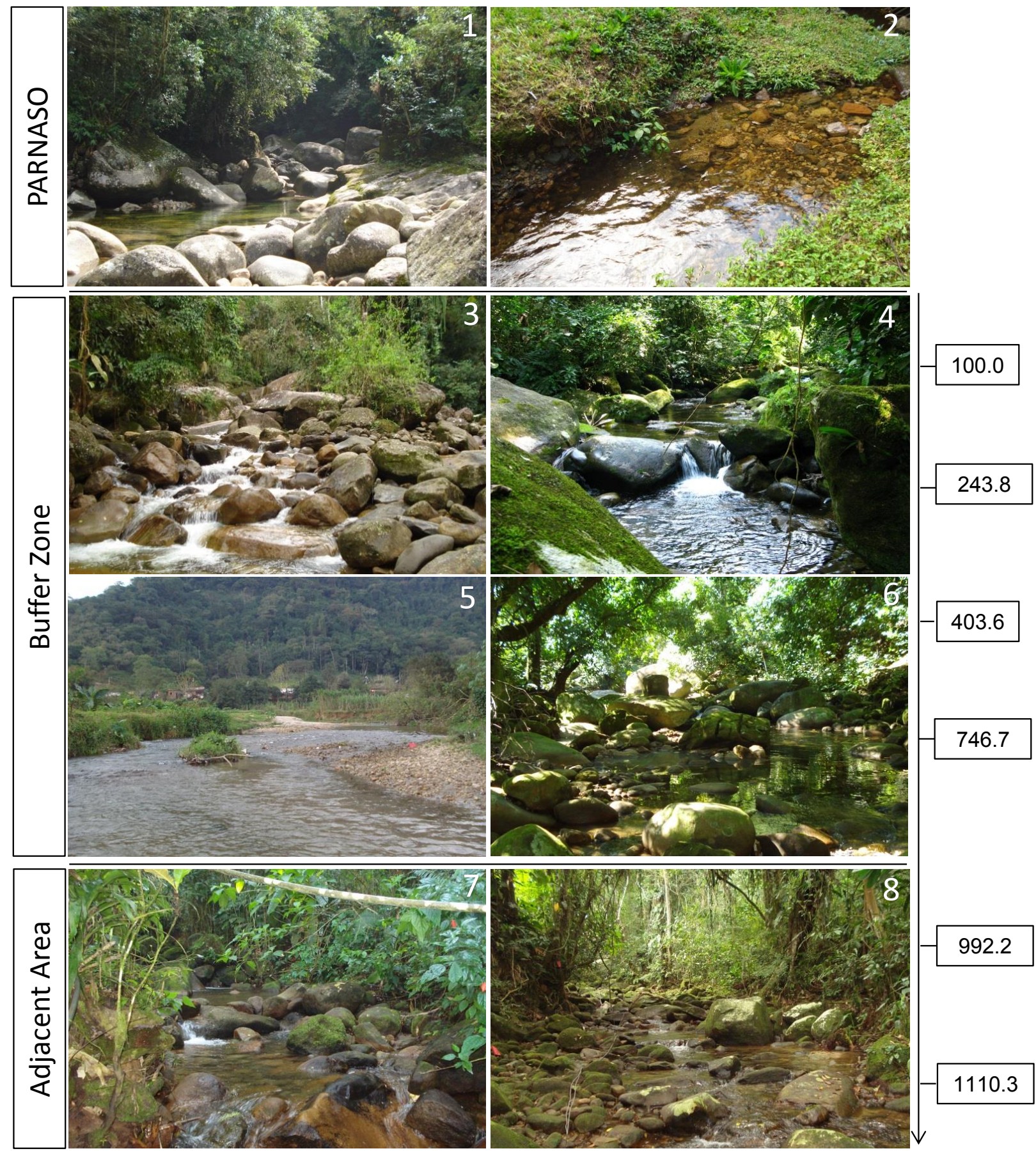

992.2

1110.3

Figure 2. Stream pictures indicating the 14 Atlantic Rain Forest stream sites arranged according to their position in relation to Parque Nacional da Serra dos Órgãos. Numbers in each picture indicates their code. Odd numbers correspond to first distance from top to bottom. The arrow with numbers indicates the distance in meters from the park boarder. 
Table 1. Physical characteristics of the 14 Atlantic Forest stream sites sampled in the Parque Nacional da Serra dos Órgãos and its surrounding areas, southeastern Brazil.

\begin{tabular}{|c|c|c|c|c|c|c|c|}
\hline $\begin{array}{l}\text { Position relative } \\
\text { to PARNASO }\end{array}$ & River/stream & Code & $\begin{array}{l}\text { Latitude } \\
\text { (geo/WGS84) }\end{array}$ & $\begin{array}{l}\text { Longitude } \\
\text { (geo/WGS84) }\end{array}$ & $\begin{array}{l}\text { Mean width } \\
\text { (m) }\end{array}$ & $\begin{array}{l}\text { Channel length } \\
\text { sampled }(\mathrm{m})\end{array}$ & $\begin{array}{l}\text { Altitude } \\
\text { (m a.s.I.) }\end{array}$ \\
\hline PARNASO & Soberbo & 1 & $22^{\circ} 29^{\prime} 39^{\prime \prime}$ & $043^{\circ} 59^{\prime} 53^{\prime \prime}$ & 4 & 160 & 340 \\
\hline PARNASO & Santinha* & 2 & $22^{\circ} 27^{\prime} 59^{\prime \prime}$ & $043^{\circ} 00^{\prime} 09^{\prime \prime}$ & 15 & 160 & 862 \\
\hline Buffer zone & Santo Aleixo & 3 & $22^{\circ} 31^{\prime} 30^{\prime \prime}$ & $043^{\circ} 01^{\prime} 53^{\prime \prime}$ & 5 & 200 & 261 \\
\hline Buffer zone & Pedras Negras & 4 & $22^{\circ} 32^{\prime} 34^{\prime \prime}$ & $043^{\circ} 03^{\prime} 59^{\prime \prime}$ & 7 & 280 & 207 \\
\hline Buffer zone & Caioba & 5 & $22^{\circ} 35^{\prime} 12^{\prime \prime}$ & $043^{\circ} 11^{\prime} 03^{\prime \prime}$ & 8 & 320 & 20 \\
\hline Buffer zone & Rio Piabetá & 6 & $22^{\circ} 35^{\prime} 02^{\prime \prime}$ & $043^{\circ} 09^{\prime} 57^{\prime \prime}$ & 8 & 320 & 35 \\
\hline Adjacent area & $\begin{array}{l}\text { Rio dos Caval- } \\
\text { heiros }\end{array}$ & 7 & $22^{\circ} 35^{\prime} 36^{\prime \prime}$ & $043^{\circ} 07^{\prime} 19^{\prime \prime}$ & 4 & 160 & 12 \\
\hline Adjacent area & Rio do Ouro & 8 & $22^{\circ} 35^{\prime} 32^{\prime \prime}$ & $043^{\circ} 06^{\prime} 44^{\prime \prime}$ & 4 & 160 & 43 \\
\hline Adjacent area & Valinha & 9 & $22^{\circ} 35^{\prime} 49^{\prime \prime}$ & $043^{\circ} 08^{\prime} 34^{\prime \prime}$ & 0.5 & 100 & 43 \\
\hline Adjacent area & Lava Prato & 10 & $22^{\circ} 35^{\prime} 56^{\prime \prime}$ & $043^{\circ} 08^{\prime} 47^{\prime \prime}$ & 1.5 & 100 & 14 \\
\hline Adjacent area & Cachoeirinha & 11 & $22^{\circ} 35^{\prime} 28^{\prime \prime}$ & $043^{\circ} 05^{\prime} 26^{\prime \prime}$ & 4 & 160 & 33 \\
\hline Adjacent area & Rio da Rainha & 12 & $22^{\circ} 36^{\prime} 11^{\prime \prime}$ & $043^{\circ} 09^{\prime} 10^{\prime \prime}$ & 1.5 & 100 & 18 \\
\hline Adjacent area & Roncador I & $13(14)$ & $22^{\circ} 35^{\prime} 27^{\prime \prime}$ & $043^{\circ} 04^{\prime} 37^{\prime \prime}$ & 2 & 100 & 12 \\
\hline Adjacent area & Roncador II & $14(13)$ & $22^{\circ} 35^{\prime} 09^{\prime \prime}$ & $043^{\circ} 04^{\prime} 90^{\prime \prime}$ & 2 & 100 & 12 \\
\hline
\end{tabular}

Characidae was the family with the highest number of species (13 species), followed by Loricariidae (11 species). The Characidae family also had the highest number of individuals (40\% of the total number of individuals), followed by Poeciliidae ( $15 \%$ of individuals).

Astyanax taeniatus (Jenyns, 1842) represented 19.2\% of the total number of individuals and $22 \%$ of total biomass, occurring mainly in streams in the buffer area. Poecilia reticulata Peters, 1859 was the second most abundant species ( $12 \%$ of the total number of individuals); however the second highest biomass was recorded for Rhamdia quelen (Quoy \& Gaimard, 1824) (15\%). Phalloceros harpagos Lucinda, 2008 was the most frequent species, occurring in 10 of the 14 streams. Poecilia reticulata and Xiphophorus sp. (only one individual in the adjacent area) were the only recorded non-native species.

A total of 12 species was recorded within the PARNASO limiting area (Table 2), therefore doubles the number of species originally recorded in the management plan for the conservation unit. One of the six species previously recorded in the park management plan (Trichomycterus goeldii Boulenger, 1896) was not recorded in this study. We collected Characidium vidali Travassos, 1967 and the management plan listed Characidium sp. n., although we cannot ensure they are the same species. Fish assemblage composition within the PARNASO limits differed from those recorded in streams from the adjacent area (Figure 3). Moreover, streams in the buffer area have intermediary ichthyofauna composition between the PARNASO and the adjacent area. Two species were found only in the sites within the PARNASO limits (Crenicichla lacustris (Castelnau, 1855) and Trichomycterus cf. paquequerense (Miranda Ribeiro, 1943)). Poecilia vivipara Bloch \& Schneider, 1801, Rhamdioglanis transfasciatus Miranda Ribeiro, 1908, Astyanax intermedius Eigenmann, 1908, Rineloricaria sp.
2, Hypostomus sp., Astyanax sp., Callichthys callichthys (Linnaeus, 1758), and Kronichthys heylandi (Boulenger, 1900) were collected only in the buffer area, whereas other 11 species were found only in the adjacent area.

\section{DISCUSSION}

The predominance of Siluriformes and Characiformes as main components of the ichthyofauna of the Atlantic Rain Forest streams was expected because they are the dominant orders in Neotropical freshwater systems (Lowe-McConnell 1999; Abilhoa et al. 2011) and were also observed in Atlantic Rain Forest streams (Casatti et al. 2001; Sarmento-Soares et al. 2007; Ferreira and Petrere 2009).

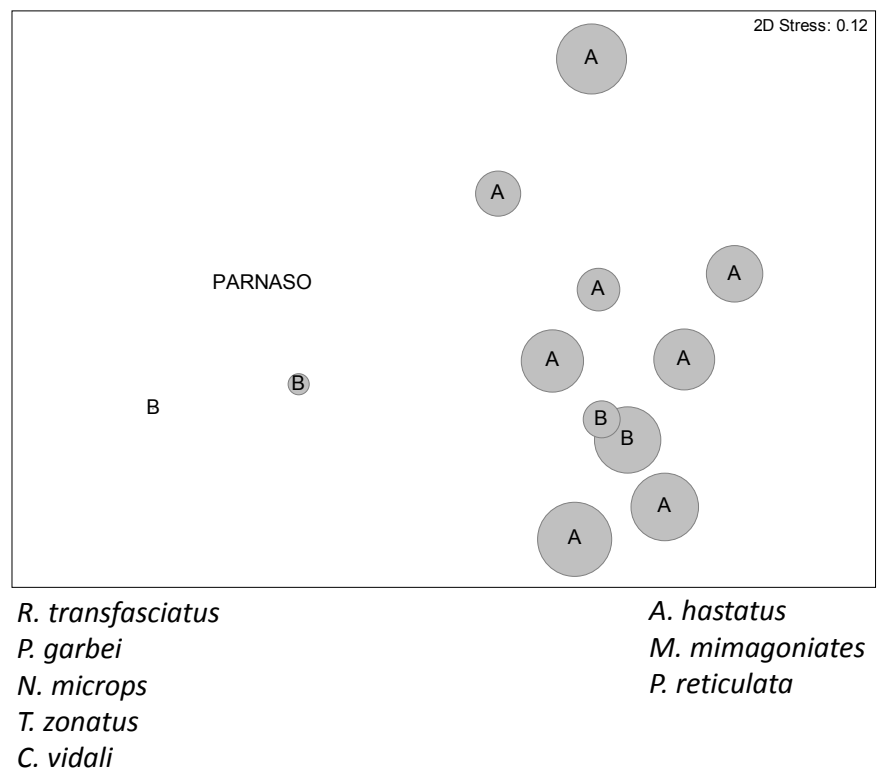

Figure 3. MDS plots of fish assemblages at each of the 14 Atlantic Rain Forest sites based on Bray-Curtis similarity measures. The species associated with the sites were shown in the bottom of the figure. The distance from each site sample to the PARNASO is shown using scaled bubbles. Scale of bubbles $0-4000$ meters. $A=$ adjacent area and $B=$ buffer zone. 
Table 2. List of species collected in the 14 Atlantic Rain Forest stream sites sampled in the Parque Nacional da Serra dos Órgãos, buffer zone and its adjacent areas. $\mathrm{N}=$ Number of individuals. $\mathrm{B}=$ Biomass in grams. $\mathrm{FO} \%=$ Frequency of occurrence. $\mathrm{X}=$ Species recorded in the PARNASO Management Plan. Gray color indicates species sampled in within the area.

\begin{tabular}{|c|c|c|c|c|c|c|}
\hline Species & $\mathbf{N}$ & $B(g)$ & FO\% & PARNASO & Buffer & Adjacent \\
\hline Characidium vidali Travassos, 1967 & 383 & 816.25 & 50.0 & $x$ & & \\
\hline Astyanax giton Eigenmann, 1908 & 147 & 796.95 & 42.9 & & & \\
\hline Astyanax hastatus Myers, 1928 & 187 & 199.06 & 42.9 & & & \\
\hline Astyanax parahybae Eigenmann, 1908 & 25 & 19.31 & 7.1 & & & \\
\hline Astyanax sp. 1 & 2 & 24.43 & 7.1 & & & \\
\hline Astyanax sp. 2 & 1 & 4.6 & 7.1 & & & \\
\hline Astyanax taeniatus (Jenyns, 1842) & 886 & 5362.39 & 42.9 & & & \\
\hline Bryconamericus ornaticeps Bizerril \& Perez-Neto, 1995 & 134 & 346.75 & 21.4 & & & \\
\hline \multicolumn{7}{|l|}{ Erythrinidae } \\
\hline Hoplias malabaricus (Bloch, 1794) & 12 & 1144.75 & 21.4 & & & \\
\hline \multicolumn{7}{|l|}{ CYPRINODONTIFORMES } \\
\hline \multicolumn{7}{|l|}{ Rivulidae } \\
\hline Kryptolebias brasiliensis (Valenciennes, 1821) & 3 & 1.25 & 21.4 & & & \\
\hline \multicolumn{7}{|l|}{ Poeciliidae } \\
\hline Phalloceros aff. anisophallos Lucinda, 2008 & 6 & 0.99 & 7.1 & & & \\
\hline Phalloceros harpagos Lucinda, 2008 & 95 & 17.36 & 71.4 & & & \\
\hline Poecilia reticulata* Peters, 1859 & 568 & 106.62 & 57.1 & & & \\
\hline Poecilia vivipara Bloch \& Schneider, 1801 & 6 & 1.21 & 14.3 & & & \\
\hline Xiphophorus sp. ${ }^{*}$ & 1 & 1.12 & 7.1 & & & \\
\hline
\end{tabular}

\begin{tabular}{ll} 
Xiphophorus sp.* $^{*}$ & 1 \\
\hline GYMNOTIFORMES &
\end{tabular}

\section{Gymnotidae}

Gymnotus carapo Linnaeus, $1758 \quad 2 \quad 29.62$

Gymnotus pantherinus (Steindachner, 1908) $\quad 29 \quad 387.69 \quad 28.6$

\section{PERCIFORMES}

\section{Cichlidae}

Crenicichla lacustris (Castelnau, 1855)

Geophagus brasiliensis (Quoy\&Gaimard, 1824)

Gobiidae

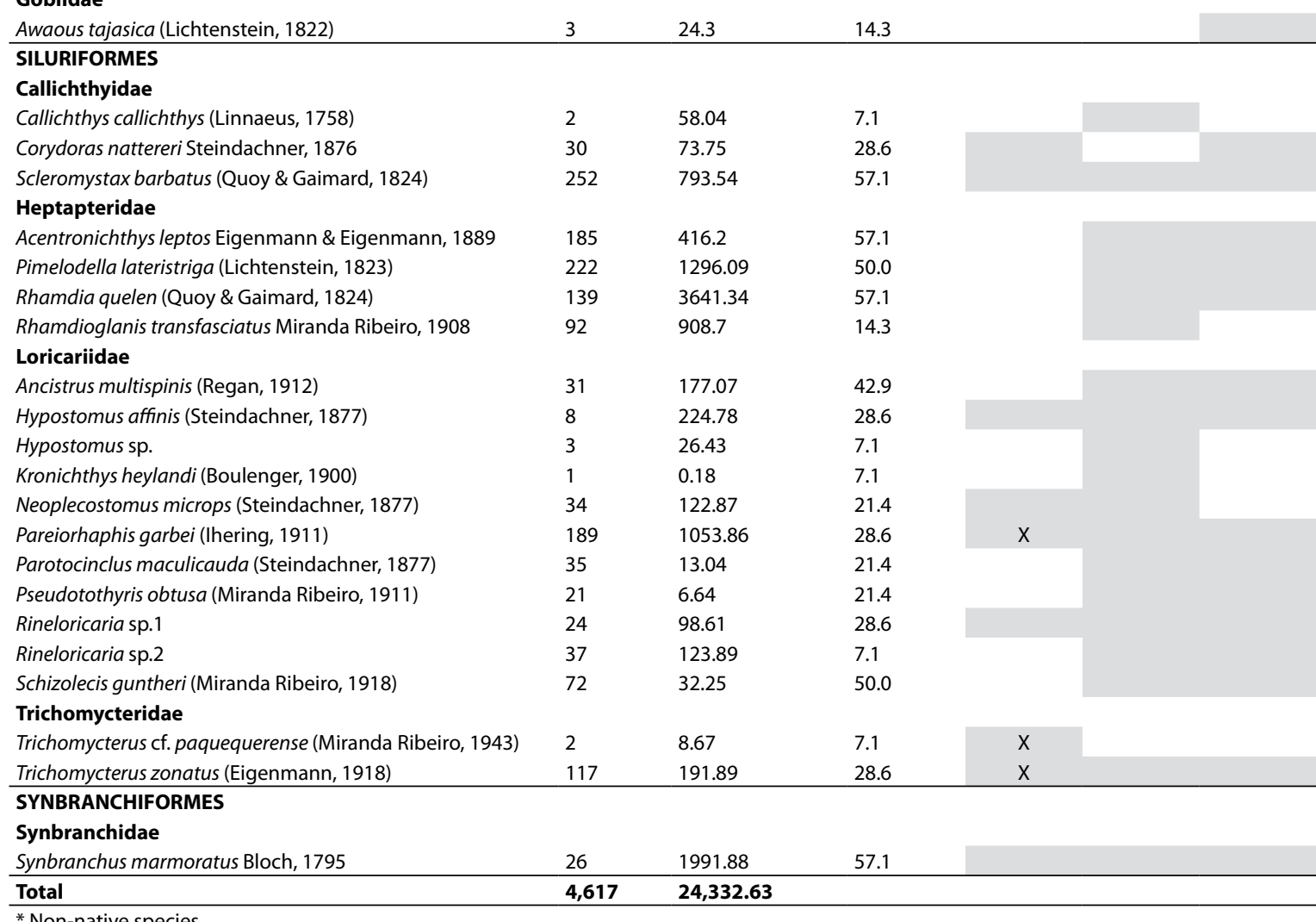

* Non-native species. 
The opportunist species Astyanax taeniatus and Poecilia reticulata that had the highest total number of individuals colonized several types of habitats. Characins inhabit several aquatic habitats such as streams, rivers, lagoons and reservoirs in different levels of environmental quality, whereas the poecilids are known for their capacity to colonize a wide range of degraded habitats tolerating low water quality where other species cannot tolerate (Araújo et al. 2009; Teixeira et al. 2005).

From species that were exclusively collected within PARNASO limits, Crenicichla lacustris is a widely distributed species over coastal drainages of the Southeastern and Eastern Brazil (FishBase 26/11/2014). However, T. cf. paquequerense that was considered endemic for the Paquequer River basin (also located within the PARNASO limiting area) was recorded for the first time in this study for the Soberbo River. This species is typical of cold and turbulent waters with special habitat requirements.

In the buffer zone, we found both, species more sensible to environmental disturbance (e.g., sewage discharges, channelization, lack of riparian cover) such as $R$. transfasciatus, and more tolerant species to environmental degradation such as the non-native $P$. reticulata, the characins of Astyanax genera and the siluriformes Rineloricaria sp. 2. In the adjacent area where human interference such as residences near the stream margins, small dams for recreation, poultry activities, small plantation, among others we recorded species typical of lowland areas that inhabit sites with comparatively high temperature and with high pool availability.

Altitude has been reported as an important environmental variable determining fish assemblage structure in streams (Ferreira and Petrere 2009). However, fish responses to altitudinal gradient can be confounding with anthropogenic impacts that are more common in low altitudes. Streams within the PARNASO limits and in its buffer area have comparatively higher altitude and have comparatively lower species richness that are associated with fast waters (rapids and runs), higher dissolved oxygen and comparatively lower temperature (River Continuum Concept, Vannote et al. 1980). Species of Trichomycterus and the Characidium vidali are typical representative of such areas. On the other hand, decreasing slope, increasing temperature and high availability of pools contribute to changes in the substrate type of downstream sites favoring the occupation of the stream habitat by other species adapted to these conditions as we found in the adjacent area of the PARNASO.

This study contributed to enhanced knowledge on the fish assemblage composition and structure in the PARNASO streams, recording six new species for the area that were not included in the management plan of this conservation unit. Knowledge on the community's composition and distribution is a main concern considering the high pressure of human activities on several of the world aquatic ecosystems (Duncan and Lockwood 2001; Aquino et al. 2009). This is a main step to elaborate and to establish management plans aiming conservation and recovery of aquatic ecosystems.

\section{ACKNOWLEDGEMENTS}

We thank the Parque Nacional da Serra dos Órgãos for the access and accommodation. We also thank the team of Laboratório de Ecologia de Peixes (UFRuralRJ), for their assistance in the field and Professor Wilson Costa (UFRJ) for helping with fish identification. This research was partially funded by FAPERJ (Fundação de Amparo à Pesquisa do Estado do Rio de Janeiro). GSC and FGA were sponsored by the Conselho Nacional de Desenvolvimento Científico e Tecnológico ( $\mathrm{CNPq}$ ) and BFT was sponsored by Coordenação de Aperfeiçoamento de Pessoal de Nível Superior (CAPES).

\section{LITERATURE CITED}

Abilhoa, V., R.R. Braga, H. Bornatowski and J.R.S Vitule. 2011. Fishes of the Atlantic Rain Forest streams: ecological patterns and conservation, pp. 259-282, in: O. Grillo and G. Venora (eds.). Changing diversity in changing environmental. Rijeka: InTech.

Aquino, P.P.U., M. Schneider, M.S.M. Silva, C.P. Fonseca, H.B. Arakawa and D.R. Cavalcanti. 2009. Ictiofauna dos córregos do Parque Nacional de Brasília, bacia do Alto Rio Paraná, Distrito Federal, Brasil Central. Biota Neotropica 9(1): 217-230. http:// www.biotaneotropica.org.br/vgn1/en/abstract?inventory +bno2809012009

Araújo, F.G., M.G. Peixoto, B.C.T. Pinto and T.P. Teixeira. 2009. Distribution of guppies Poecilia reticulata (Peters, 1860) and Phalloceros caudimaculatus (Hensel, 1868) along a polluted stretch of the Paraíba do Sul river, Brazil. Brazilian Journal of Biology 69(1): 41-48. doi: 10.1590/S1519-69842009000100005

Bragagnolo, C. and Pinto-da-Rocha, R. 2003. Diversidade de opiliões do Parque Nacional da Serra dos Órgãos, Rio de Janeiro, Brasil (Arachnida: Opiliones). Biota Neotropica 3(1): 1-2o. http://www. biotaneotropica.org.br/v3n1/pt/abstract?article+BNoo2030 12003

Casatti, L., F. Langeani and R.M.C. Castro. 2001. Peixes de riacho do Parque Estadual Morro do Diabo, bacia do Alto Rio Paraná, SP. Biota Neotropica 1(1): 1-15. http://www.biotaneotropica.org.br/ v2n2/pt/abstract?article+BNo2502022002

Clarke, K.R. and R. N. Gorley. 2006. PRIMER v6: User Manual/ Tutorial. PRIMER-E, Plymouth.

Drummond, J.A. 1997. Devastação e Preservação Ambiental, Os Parques Nacionais do Estado do Rio de Janeiro. Rio de Janeiro: EDUFF. 306 pp.

Duncan, J.R. and J.L. Lockwood. 2001. Extinction in a field of bullets: a search for causes in the decline of world's freshwater fishes. Biological Conservation 102(1): 97-105. doi: 10.1016/Sooo6-3207 (01) $00077-5$

Ferreira, F.C. and M. Petrere. 2009. The fish zonation of the Itanhaém river basin in the Atlantic Forest of southeast Brazil. Hydrobiologia 636(1): 11-34. doi: 10.1007/s10750-009-9932-4

FishBase. 2014. FishBase: a global information system on fishes. Accessed at http://www.fishbase.org/home.htm, 26 November 
2014.

Guimarães, R.F., Gomes, R.A.T., Júnior, O.A.C., Martins, E.S., Oliveira, S.N. and Fernandes, N.F. 2009. Análise temporal das áreas susceptíveis a escorregamentos rasos no Parque Nacional da Serra dos Órgãos (RJ) a partir de dados pluviométricos. Revista Brasileira de Geociências 39(1): 190-198. http://rbg. sbgeo.org.br/index.php/rbg/article/view/1451/1143

Guimarães, A.T.B., M.S. Menezes and A.C. Peret. 2010. Composição da ictiofauna em função da fisiografia de um riacho costeiro de Floresta Atlântica - Brasil. Biota Neotropica 10(2): 57-66. http:// www.biotaneotropica.org.br/v1on2/en/abstract?article+bno101 0022010

Lowe-McConnell, R.H. 1999. A fauna de peixes neotropical, pp. 129-168, in: R. H. Lowe-McConnell (ed.). Estudos ecológicos de comunidades de peixes tropicais. São Paulo: EDUSP.

Miranda, J.C. 2012. Ameaças aos peixes de riachos da Mata Atlântica. Natureza on line 10(3): 136-139. http://www.naturezaonline. com.br/natureza/conteudo/pdf/o7_MirandaJC_136139.pdf

Myers, N., C.G. Mittermeier, G.A.B. Fonseca and J. Kent. 2000. Biodiversity hotspots for conservation priorities. Nature 408: 853-858. doi: 10.1038/35002501

Ranta, P., T. Blom, J. Niemelä, E. Joensuu and M. Siitonen. 1998. The fragmented Atlantic rain forest of Brazil: size, shape and distribution of forest fragments. Biodiversity and Conservation 7: 385-403. doi: 10.1023/A:1008885813543

Ribeiro, M.C., J.P. Metzger, A.C. Martensen, F.J. Ponzoni and M.M. Hirota. 2009.The Brazilian Atlantic Forest: How much is left, and how is the remaining forest distributed? Implications for conservation. Biological Conservation 142: 1141-1153. doi: 10.1016/j.biocon.2009.02.021

Sarmento-Soares, L.M., R. Mazzoni and R.F. Martins-Pinheiro. 2007. A fauna de peixes na bacia do Rio Peruípe, extremo Sul da Bahia. Biota Neotropica 7(3): 291-307. doi: 10.1590/S167606032007000300031

Silva, W.G.S., J.P. Metzger, S. Simões and C. Simonetti. 2007. Relief influence on the spatial distribution of the Atlantic Forest cover at the Ibiúna Plateau, SP. Brazilian Journal of Biology 67(3): 403-411. doi: 10.1590/S1519-69842007000300004

Tabarelli, M., A.V. Aguiar, M.C. Ribeiro, J.P. Metzger and C.A. Peres. 2010. Prospects for biodiversity conservation in the Atlantic Forest: Lessons from aging human-modified landscapes. Biological Conservation 143(10): 2328-2340. doi: 10.1016/j. biocon.2010.02.005

Teixeira, T.P., B.C.T. Pinto, B.F. Terra, E.O. Estiliano, D. Gracia and F.G. Araújo. 2005. Diversidade das assembleias de peixes nas quatro unidades geográficas do rio Paraíba do Sul. Iheringia, Serie Zoologica 95(4): 347-357. doi: 10.1590/Soo7347212005000400002

Terra, B.F., R.M. Hughes, M.R. Francelino and F.G. Araújo. 2013. Sampling sufficiency for fish assemblage surveys of tropical Atlantic Forest streams, Southeastern Brazil. Fisheries 38(4): 150-158. doi: 10.1080/03632415.2013.775572

Vannote, R.L., G.W. Minshall, K.W. Cummins, J.R. Sedell and C.E. Cushing. 1980. The River Continuum Concept. Canadian Journal of Fisheries and Aquatic Sciences 37(1): 130-137.

doi: 10.1139/f80-017

Authors' contribution statement: GSC and BFT collected the data, GSC, BFT and FGA wrote the text, and GSC and BFT made the analyses.

Received: 25 January 2015

Accepted: 28 April 2015

Academic Editor: Tiago P. Carvalho

\section{Appendix 1}

Table A1. Voucher numbers and geographic coordinates of the specimen deposited in fish collection of the Laboratory of Fish Ecology, Universidade Federal Rural do Rio de Janeiro and in the Special Teleost at Fish Collection of the Universidade Federal do Rio de Janeiro.

\begin{tabular}{|c|c|c|c|}
\hline Vouchers numbers & Species & Streams & Geographic coordinates \\
\hline UFRRJ-LEP866 & Characidium vidali & Pedras Negras & $22^{\circ} 32^{\prime} 34^{\prime \prime} \mathrm{S}, 043^{\circ} 03^{\prime} 59^{\prime \prime} \mathrm{W}$ \\
\hline UFRRJ-LEP798 & Astyanax giton & Cachoeirinha & $22^{\circ} 35^{\prime} 28^{\prime \prime} \mathrm{S}, 043^{\circ} 05^{\prime} 26^{\prime \prime} \mathrm{W}$ \\
\hline UFRRJ-LEP846 & Astyanax hastatus & Caioba & $22^{\circ} 35^{\prime} 12^{\prime \prime} \mathrm{S}, 043^{\circ} 11^{\prime} 03^{\prime \prime} \mathrm{W}$ \\
\hline UFRRJ-LEP793 & Astyanax intermedius & Piabetá & $22^{\circ} 35^{\prime} 02^{\prime \prime} \mathrm{S}, 043^{\circ} 09^{\prime} 57^{\prime \prime} \mathrm{W}$ \\
\hline UFRRJ-LEP825 & Astyanax janeiroensis & Roncador II & $22^{\circ} 35^{\prime} 09^{\prime \prime} \mathrm{S}, 043^{\circ} 04^{\prime} 90^{\prime \prime} \mathrm{W}$ \\
\hline UFRRJ-LEP871 & Astyanax parahybae & Roncador II & $22^{\circ} 35^{\prime} 09^{\prime \prime} \mathrm{S}, 043^{\circ} 04^{\prime} 90^{\prime \prime} \mathrm{W}$ \\
\hline UFRRJ-LEP1525 & Astyanax sp. 1 & Caioba & $22^{\circ} 35^{\prime} 12^{\prime \prime} \mathrm{S}, 043^{\circ} 11^{\prime} 03^{\prime \prime} \mathrm{W}$ \\
\hline UFRRJ-LEP1526 & Astyanax sp. 2 & Cachoeirinha & $22^{\circ} 35^{\prime} 28^{\prime \prime} \mathrm{S}, 043^{\circ} 05^{\prime} 26^{\prime \prime} \mathrm{W}$ \\
\hline UFRRJ-LEP794 & Astyanax taeniatus & Caioba & $22^{\circ} 35^{\prime} 12^{\prime \prime} \mathrm{S}, 043^{\circ} 11^{\prime} 03^{\prime \prime} \mathrm{W}$ \\
\hline UFRRJ-LEP836 & Bryconamericus ornaticeps & Cachoeirinha & $22^{\circ} 35^{\prime} 28^{\prime \prime} \mathrm{S}, 043^{\circ} 05^{\prime} 26^{\prime \prime} \mathrm{W}$ \\
\hline UFRRJ-LEP1527 & Deuterodon sp. 1 & Cachoeirinha & $22^{\circ} 35^{\prime} 28^{\prime \prime} \mathrm{S}, 043^{\circ} 05^{\prime} 26^{\prime \prime} \mathrm{W}$ \\
\hline UFRRJ-LEP1528 & Deuterodon sp.2 & Roncador II & $22^{\circ} 35^{\prime} 09^{\prime \prime} \mathrm{S}, 043^{\circ} 04^{\prime} 90^{\prime \prime} \mathrm{W}$ \\
\hline UFRRJ-LEP1529 & Hyphessobrycon reticulatus & Roncador II & $22^{\circ} 35^{\prime} 09^{\prime \prime} \mathrm{S}, 043^{\circ} 04^{\prime} 90^{\prime \prime} \mathrm{W}$ \\
\hline UFRRJ-LEP839 & Mimagoniates microlepis & Rainha & $22^{\circ} 36^{\prime} 11^{\prime \prime} \mathrm{S}, 043^{\circ} 09^{\prime} 10^{\prime \prime} \mathrm{W}$ \\
\hline UFRRJ-LEP844 & Hoplias malabaricus & Roncador I & $22^{\circ} 35^{\prime} 27^{\prime \prime} \mathrm{S}, 043^{\circ} 04^{\prime} 37^{\prime \prime} \mathrm{W}$ \\
\hline UFRRJ-LEP1136 & Kryptolebias brasiliensis & Imbariê & $22^{\circ} 35^{\prime} 04^{\prime \prime} \mathrm{S}, 043^{\circ} 11^{\prime} 46^{\prime \prime} \mathrm{W}$ \\
\hline UFRRJ-LEP1531 & Phalloceros aff. anisophallos & Rainha & $22^{\circ} 36^{\prime} 11^{\prime \prime} \mathrm{S}, 043^{\circ} 09^{\prime} 10^{\prime \prime} \mathrm{W}$ \\
\hline UFRRJ-LEP957 & Phalloceros harpagos & Pedras Negras & $22^{\circ} 32^{\prime} 34^{\prime \prime} \mathrm{S}, 043^{\circ} 03^{\prime} 59^{\prime \prime} \mathrm{W}$ \\
\hline UFRRJ-LEP952 & Poecilia reticulata & Roncador I & $22^{\circ} 35^{\prime} 27^{\prime \prime} \mathrm{S}, 043^{\circ} 04^{\prime} 37^{\prime \prime} \mathrm{W}$ \\
\hline UFRRJ-LEP1532 & Poecilia vivipara & Caioba & $22^{\circ} 35^{\prime} 12^{\prime \prime} \mathrm{S}, 043^{\circ} 11^{\prime} 03^{\prime \prime} \mathrm{W}$ \\
\hline UFRRJ-LEP982 & Xiphophorus sp. & Roncador I & $22^{\circ} 35^{\prime} 27^{\prime \prime} \mathrm{S}, 043^{\circ} 04^{\prime} 37^{\prime \prime} \mathrm{W}$ \\
\hline UFRRJ-LEP1534 & Gymnotus carapo & Rainha & $22^{\circ} 36^{\prime} 11^{\prime \prime} \mathrm{S}, 043^{\circ} 09^{\prime} 10^{\prime \prime} \mathrm{W}$ \\
\hline UFRJ8523 & Gymnotus pantherinus & Rio do Ouro & $22^{\circ} 35^{\prime} 32^{\prime \prime} \mathrm{S}, 043^{\circ} 06^{\prime} 44^{\prime \prime} \mathrm{W}$ \\
\hline UFRRJ-LEP1535 & Crenicichla lacustris & Soberbo & $22^{\circ} 29^{\prime} 39^{\prime \prime} \mathrm{S}, 042^{\circ} 59^{\prime} 53^{\prime \prime} \mathrm{W}$ \\
\hline UFRRJ-LEP965 & Geophagus brasiliensis & Roncador I & $22^{\circ} 35^{\prime} 27^{\prime \prime} \mathrm{S}, 043^{\circ} 04^{\prime} 37^{\prime \prime} \mathrm{W}$ \\
\hline UFRRJ-LEP972 & Awaous tajasica & Rainha & $22^{\circ} 36^{\prime} 11^{\prime \prime} \mathrm{S}, 043^{\circ} 09^{\prime} 10^{\prime \prime} \mathrm{W}$ \\
\hline
\end{tabular}


Table A1. Continued.

\begin{tabular}{|c|c|c|c|}
\hline Vouchers numbers & Species & Streams & Geographic coordinates \\
\hline UFRRJ-LEP1536 & Callichthys callichthys & Caioba & $22^{\circ} 35^{\prime} 12^{\prime \prime} \mathrm{S}, 043^{\circ} 11^{\prime} 03^{\prime \prime} \mathrm{W}$ \\
\hline UFRRJ-LEP931 & Corydoras nattereri & Roncador I & $22^{\circ} 35^{\prime} 27^{\prime \prime} \mathrm{S}, 043^{\circ} 04^{\prime} 37^{\prime \prime} \mathrm{W}$ \\
\hline UFRRJ-LEP891 & Scleromystax barbatus & Cachoeirinha & $22^{\circ} 35^{\prime} 28^{\prime \prime} \mathrm{S}, 043^{\circ} 05^{\prime} 26^{\prime \prime} \mathrm{W}$ \\
\hline UFRRJ-LEP916 & Acentronichthys leptos & Caioba & $22^{\circ} 35^{\prime} 12^{\prime \prime} \mathrm{S}, 043^{\circ} 11^{\prime} 03^{\prime \prime} \mathrm{W}$ \\
\hline UFRRJ-LEP919 & Pimelodella lateristriga & Roncador I & $22^{\circ} 35^{\prime} 27^{\prime \prime} \mathrm{S}, 043^{\circ} 04^{\prime} 37^{\prime \prime} \mathrm{W}$ \\
\hline UFRRJ-LEP937 & Rhamdia quelen & Roncador I & $22^{\circ} 35^{\prime} 27^{\prime \prime} \mathrm{S}, 043^{\circ} 04^{\prime} 37^{\prime \prime} \mathrm{W}$ \\
\hline UFRRJ-LEP927 & Rhamdioglanis transfasciatus & Pedras Negras & $22^{\circ} 32^{\prime} 34^{\prime \prime} \mathrm{S}, 043^{\circ} 03^{\prime} 59^{\prime \prime} \mathrm{W}$ \\
\hline UFRRJ-LEP880 & Ancistrus multispinis & Pedras Negras & $22^{\circ} 32^{\prime} 34^{\prime \prime} \mathrm{S}, 043^{\circ} 03^{\prime} 59^{\prime \prime} \mathrm{W}$ \\
\hline UFRRJ-LEP1538 & Hypostomus affinis & Rainha & $22^{\circ} 36^{\prime} 11^{\prime \prime} \mathrm{S}, 043^{\circ} 09^{\prime} 10^{\prime \prime} \mathrm{W}$ \\
\hline UFRRJ-LEP1539 & Hypostomus sp. & Caioba & $22^{\circ} 35^{\prime} 12^{\prime \prime} \mathrm{S}, 043^{\circ} 11^{\prime} 03^{\prime \prime} \mathrm{W}$ \\
\hline UFRRJ-LEP1540 & Kronichthys heylandi & Santo Aleixo & $22^{\circ} 31^{\prime} 30^{\prime \prime} \mathrm{S}, 043^{\circ} 01^{\prime} 53^{\prime \prime} \mathrm{W}$ \\
\hline UFRRJ-LEP929 & Neoplecostomus microps & Pedras Negras & $22^{\circ} 32^{\prime} 34^{\prime \prime} \mathrm{S}, 043^{\circ} 03^{\prime} 59^{\prime \prime} \mathrm{W}$ \\
\hline UFRRJ-LEP1537 & Pareiorhaphis garbei & Santo Aleixo & $22^{\circ} 31^{\prime} 30^{\prime \prime} \mathrm{S}, 043^{\circ} 01^{\prime} 53^{\prime \prime} \mathrm{W}$ \\
\hline UFRRJ-LEP1541 & Parotocinclus maculicauda & Caioba & $22^{\circ} 35^{\prime} 12^{\prime \prime} \mathrm{S}, 043^{\circ} 11^{\prime} 03^{\prime \prime} \mathrm{W}$ \\
\hline UFRRJ-LEP901 & Pseudotothyris obtusa & Rainha & $22^{\circ} 36^{\prime} 11^{\prime \prime} \mathrm{S}, 043^{\circ} 09^{\prime} 10^{\prime \prime} \mathrm{W}$ \\
\hline UFRRJ-LEP1542 & Rineloricaria sp.1 & Caioba & $22^{\circ} 35^{\prime} 12^{\prime \prime} \mathrm{S}, 043^{\circ} 11^{\prime} 03^{\prime \prime} \mathrm{W}$ \\
\hline UFRRJ-LEP1543 & Rineloricaria sp.2 & Caioba & $22^{\circ} 35^{\prime} 12^{\prime \prime} \mathrm{S}, 043^{\circ} 11^{\prime} 03^{\prime \prime} \mathrm{W}$ \\
\hline UFRRJ-LEP911 & Schizolecis guntheri & Cavalheiros & $22^{\circ} 35^{\prime} 36^{\prime \prime} \mathrm{S}, 043^{\circ} 07^{\prime} 19^{\prime \prime} \mathrm{W}$ \\
\hline UFRJ8468 & Trichomycterus cf. paquequerense & Soberbo & $22^{\circ} 29^{\prime} 39^{\prime \prime} \mathrm{S}, 042^{\circ} 59^{\prime} 53^{\prime \prime} \mathrm{W}$ \\
\hline UFRJ8481 & Trichomycterus zonatus & Pedras Negras & $22^{\circ} 32^{\prime} 34^{\prime \prime} \mathrm{S}, 043^{\circ} 03^{\prime} 59^{\prime \prime} \mathrm{W}$ \\
\hline UFRRJ-LEP977 & Synbranchus marmoratus & Roncador I & $22^{\circ} 35^{\prime} 27^{\prime \prime} \mathrm{S}, 043^{\circ} 04^{\prime} 37^{\prime \prime} \mathrm{W}$ \\
\hline
\end{tabular}

